Meta

Journal des traducteurs

Translators' Journal

\title{
Translation and Value Judgment
}

\section{Ekundayo O. Simpson}

Volume 23, numéro 3, septembre 1978

URI : https://id.erudit.org/iderudit/004155ar

DOI : https://doi.org/10.7202/004155ar

Aller au sommaire du numéro

Éditeur(s)

Les Presses de l'Université de Montréal

ISSN

0026-0452 (imprimé)

1492-1421 (numérique)

Découvrir la revue

Citer cet article

Simpson, E. O. (1978). Translation and Value Judgment. Meta, 23(3), 211-219.

https://doi.org/10.7202/004155ar d'utilisation que vous pouvez consulter en ligne.

https://apropos.erudit.org/fr/usagers/politique-dutilisation/ 


\section{Translation and Value Judgment}

Refusal to consider translation process as an aspect of linguistics, and to admit that as a discipline translation can be systematic, is often based on claims that value judgment can play a role in translation practice and evaluation. It is observed that this is often the case with those linguists whose predilection for the pseudoscientific approach to language studies makes them want to account, willy-nilly, for every aspect of language in a scientific manner. While a scientific approach must be sought for in every discipline, it is obvious that not all aspects of language would allow for this. Mysteries still abound in our knowledge of language as language. But the point to note is that attitude to translation problems is often a reflection of the attitude taken towards language in general. George Steiner $(1971,1975)$ is right then, in a way, in blaming linguistics, hence linguists, for the loopholes inherent in the very idea of translation theory.

In this essay, we shall argue that the admission that not all aspects of language can as yet be accounted for, scientifically, cannot be a safe criterion for proving that translation and its evaluation are systematically prone to value judgment. A new case will consequently be made against Quine's thesis of indeterminacy of translation, which George Steiner, incidentally, upholds.

The fact of the matter lies, in fact, in the several layers involved in translation practice and translation as an academic discipline. The first point that needs to be stressed is the dialectical relationship between freedom of choice in translating, and the lack of freedom. It is the case of « option» versus « servitude». Viewed this way, the problem is seen in clear terms and explains why text categorization is of the utmost importance in translation studies. It becomes obvious that in technical translation, for instance, servitudes take precedence over options open to the translator. What is known to be technical terminology in each of two given languages would then hardly leave any room for the whims and caprices of the translator, no matter how genial he may be.

Here, the translator has to be slave to equivalent established terminology. It is the case that the search for equivalence in technical terminology ties the hands of the translator in a way that the search for equivalent content and form cannot restrict the translator of a literary text. Indeed, the latter has an infinite number of options open to him with every literary text. Poetics, as the name implies (Gr. poiein: "create", «invent»), leaves ample room for recreation, of course within given norms of literary canons and traditions, etc. This is more so when it is realized that a text of creative writing, definitive as it may be when compared to the target language text which is still 
to come, or which when translated is still open to correction or retranslation, is itself only a virtual entity. That is, in the sense that the meaning of every artistic text depends not only on the way each reader relates and reacts to it, but also on critical reception, since not every reader can be expected to arrive at the "correct" reading, if ever that is possible. In short, a literary work of art is the sum of its interpretations, individual, critical and otherwise. This is already a far cry from the rigorous context of scientific texts. But that is the first level of the background against which value judgment and indeterminacy in translation must be viewed, a level to which text categorization is basic.

The second level concerns the study of the actual process of translation, on which so much has been said in the recent past that we can afford to be brief. At this level, what stands out clearly is the possibility of taking into account, through a systematic study, the various elements involved in the translation process. Hence it is possible to pinpoint, through analysis, techniques involved in the passage from a text in language A (SL) to that in language B (TL) (cf. Vinay and Darbelnet's "procédés de traduction"); problems of translation equivalence; text categorization with implications for equivalence, terminology and necessary «shifts» (Popovic, 1970); the question of literary tradition and equivalent literary form; comparative stylistics; bilingualism and biculturalism with attendant cases of interference and integration (W.F. Mackey, 1970).

These different elements, and others, make up translation studies for which terms like "translatology" and "translatics" (B. Harris, 1977) have been proposed. It is consequently a field in which value judgments can be reduced to an acceptable minimum.

The third angle from which the question of value judgment can be viewed is that of evaluation of the translator's work. How objectively can a translated text be judged? Given the present state of translation studies, it is possible to prefer a translated text to another one of the same original, even to reject one of the two translations outright, as a result of careful analysis. Such an analysis, which has to be systematic to be valid, makes it possible to know which of the two translations is better, more exact, or more natural, cf. Nida's «dynamic equivalence» (Nida, 1964, 1976). It might be objected that such evaluation is already value judgment in a way. But then the systematic study of translation as viewed in this context must necessarily end up with evaluation based on facts and real situations. Needless to point out that the basic aim of research into translation since the end of the Second World War has been to show that it is possible to practise and evaluate translation objectively - even from different angles (Vinay, 1975). Such research and preoccupation are highlighted in works by Vinay and Darbelnet (1958), Mounin (1963, 1976), Nida (1964), Nida and Taber (1969), Catford (1965), Brower (1959), Arrowsmith and Shattuck (1961), Holmes (1970), Brislin (1976), etc., as well as scattered articles and special editions of Meta and Babel. German and Eastern European scholars have also contributed much to make translation studies more systematic and objective (cf. Vivay 1955). And so, it is now possible to evaluate translation more objectively, and to show that quality in translation is more a result of competence than intuition. Moreover, it is the results of such research that are now used to teach translation and train future translators in 
University departments and specialized institutions and schools of translation. We have shown elsewhere how translation criticism can be valid, provided it is objective and systematic (Simpson, 1975). Such a systematic approach to translation evaluation, which will be called TLC, can be used to refute aspects of Quine's thesis of indeterminacy in translation. Before repeating the outline of such an approach, it is necessary to restate Quine's thesis as it relates to translation (Quine, 1959, 1960).

Quine's thesis on indeterminacy in translation has aroused many valid comments and reactions. But we notice that those who have taken him up on his ideas are in fact psychologists and language philosophers who are normally hardly ever interested in problems of translation per se. It is therefore not surprising that attemps to refute essential aspects of Quine's thesis bearing on translation have not taken into account vital points which the present state of translation studies could have contributed meaningfully to the discussion.

In Word and Object (1969) Quine restates points made earlier on indeterminacy in his chapter in Brower (1959). That is, that the discipline of translation is marked by systematic indeterminacy, such that, except in a few exceptional cases, there are no valid and objective criteria that would allow one to determine if a text has been well or badly translated. Quine $(1960$, p. 27$)$ therefore says:

Manuals for translating one language into another can be set up in divergent ways, all compatible with the totality of speech dispositions, yet incompatible with one another. In countless places they will diverge in giving, as their respective translations of a sentence of the one language, sentences of the other language which stand to each other in no plausible sort of equivalence however loose. The firmer the direct links of a sentence with non-verbal stimulation, of course, the less drastically its translations can diverge from one another from manual to manual.

Elsewhere, we are told that «two such translations might even be contrary in truth value, provided there is no stimulation that would encourage assent to either». The same thesis is formulated in the following terms (Quine, 1960, p. 72);

There can be no doubt that rival systems of analytical hypotheses can fit the totality of speech behaviour to perfection, and still specify mutually incompatible translations of countless sentences insusceptible of independent control.

Quine's thesis, and hypotheses, fall within the framework of his study of what he calls « radical translation». In it, he sets out to examine how a linguist can arrive at writing a bilingual dictionary which would lead to the translation of a hitherto unknown language - without the help of interpreters: "What is relevant rather to our purposes is radical translation, i.e. translation of the language of a hitherto untouched people [...]. I shall imagine that all help of interpreters is excluded » (p. 73).

The first point to note is that aspects of the above thesis relevant to translation have in fact been solved by linguists and students of translation right from the time it became obvious that the meaning of a statement cannot be divorced from its context. A statement therefore has no specific meaning outside the context that called for it. Hence, in another language, sentences supposed to have the same meaning must be seen as applying to the same source language situation. It is on this score that Quine's 
two «incompatible" sentences do not in fact represent the same reality of the source language. If they did, Quine would have had to stress this fact. But what we find is that his hypothesis creates a situation in which manuals were created independently in the same foreign language, so as to translate the same source language. The fact that each of the two manuals has at a given point the same sentence of the source language is purely accidental.

On the other hand, if the author of Word and Object had supposed that the two sentences of his hypothetical target language were each part of a long text, it would have been easy to show that each target sentence cannot necessarily be pinned down to the source sentence with which he matches it, nor for that matter part of the source text he has in mind. The point is that translation does not necessarily proceed by a sentence to sentence pairing. In other words, the grammatical or logical sentence is not always the basic translation unit; it is the whole text (cf. "compensation", Vinay and Darbelnet, 1958). And yet Quine maintains that each of the sentences in question is accepted to be the correct rendering of the same source language text. He cannot therefore be right, for the hypothesis turns out to be a mere intellectual exercise. It is wrongly assumed that it is possible to isolate a sentence and yet expect it to have a specific and universal meaning outside any context whatsoever. Moreover, the context created by Quine is no real context - two translation manuals matched against any sentence in a source language.

Furthermore, a case can be made to show that the translation of a simple English sentence such as " He went there» may give rise to a series of sentences such as would not fail to surprise even Quine. But then, and this is our main point against the question of indeterminacy as formulated by Quine, these different sentences may be justified not only by the relevant context, but also by the point of view of the translator. It would he possible to justify certain apparent deviances, for instance, by making explicit what remains implicit in the text (cf. "explicitation», Vinay and Darbelnet, 1958). Others may be the result of translation techniques like «modulation" (different point of view) in which translation highlights opposite causal relationships, where what is rendered by simple positive affirmation in the source language is carried across by double or contrary negation (cf. "contraire négative"), or indeed where an image used in the original is justifiably transferred without the use of the figure of speech. Hence the idea contained in a given sentence can be rendered in twenty different ways, all justified by context and translation techniques. What must be stressed is that it would be wrong to insist on matching each of these twenty sentences with just the original sentence "He went there", as long as the context involved is not limited to just that sentence. Hence, for instance:

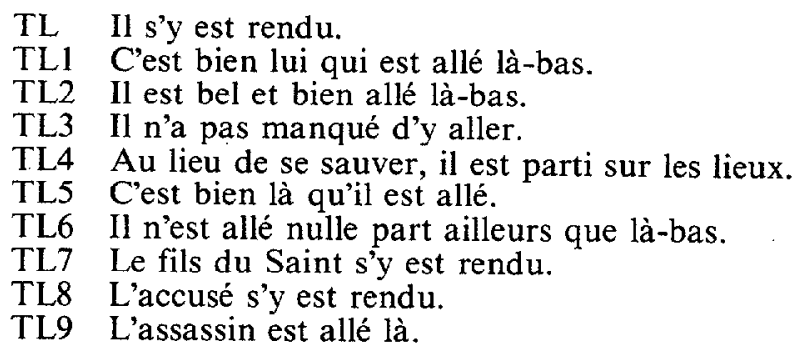




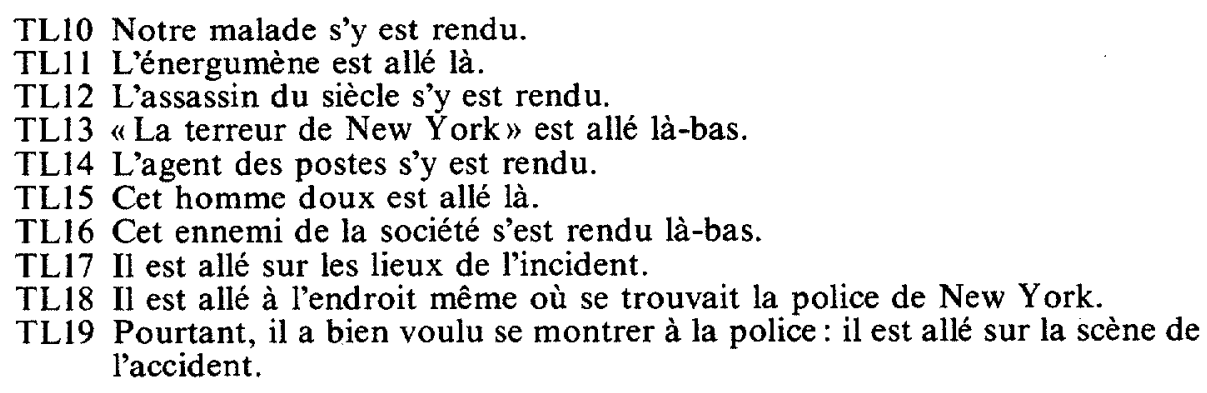

It is obvious that the full meaning of an English sentence very often depends on the word or words stressed. The role of the stress accent in English then makes it possible that when spoken, the sentence "He went there" may take on four different shades of meaning. It is possible, first of all, that none of the three words, "he", "went" or «there", is stressed, hence: SL He went there (cf. TL). The subject pronoun may be judged important and stressed:

SL 1 He went there (cf. TL 1).

The speaker may, on the other hand, be interested in stressing the action carried out, expressed by the verb:

SL $2 \mathrm{He}$ went there (cf. TL2, TL3, TL4).

Finally, the centre of interest may well be where the action took place:

SL3 He went there (cf. TL5, TL6).

Let us imagine, however, that the sentence which produced the English sentence is as follows: Several mysterious killings were recorded in the recent past in different areas of New York City. The only clues the police have, show that these acts may have been perpetrated by the same person, ironically called « the son of the Saint », judging from items always found on the scenes of the crimes. After a long period of mystery, journalists eventually take a keen interest in the incidents involving " the son of the Saint". A man is arrested at long last. He is a cool-looking occupant of a New York apartment flat, an employee of a local post office. Further investigations reveal that the suspect, who at any rate admitted responsibility for the killings, was actually in the crowd that rushed to the scene of one of the "son of the Saint " murders after it had been discovered by a neighbour who alerted the police. Psychiatric examination ordered by a court reveals that the "son of the Saint" is too sick to stand fair trial. By this time, however, the style of the killings have made the man well-known and admired in some quarters throughout the length and breadth of the country.

We shall imagine also that French-speaking newspapers are to report the incidents described above, through a report written in English after preliminary investigations. The report specifically notes that a prosecution witness, a policeman, alleged under oath that the "son of the Saint" was present at a scene to which New York police were invited after the discovery of one of the acts of the killer. Our imaginary report actually quotes the policeman as saying "He went there". What interests us here is how this sentence, idea or part of the report containing this idea, would be rendered by translators attached to French-language newspapers, or journalists who engage in translation for their newspapers. It is obvious that they would bring different points of view into that part of the text. Some translators would 
attempt, for instance, to remind their readers of aspects of « the son of the Saint » that are more or less well-known. And so, instead of the pronoun " he" (cf. SL, TL) in the original report, one would be reminded of the pseudonym (TL7), or his occupation (TL14), if not his ironic, physical appearance (TL15). Another translator may choose to approach his subject from the point of view of his society, normal society, hence "énergumène" (TL11), "ennemi" (TL16), or to see him through the eyes of the psychiatrist who finds his patient "sick" (TL10). The translator working for a newspaper that thrives on sensation and scandal would see the "cool» fellow of TL15 as the "terror" of New York (TL13) or "l'assassin du siècle» (TL12). On the other hand, the translator of a newspaper organization out to portray itself as cautious and more responsible than other organizations would bear in mind the fact that the case is still pending in court, and therefore present the man as no more than « the accused" (TL18).

These are all explicative devices, albeit operating from different view-points, and all revolving round the central character, the subject « he ». The same phenomenon can be illustrated with regard to place in the same context. Adverbial phrases and clauses would replace the simple adverb and tell more about the place of the action « went » (cf. TL17, TL18). As for the last example (TL19), it explains the whole purpose of the character's action. All the examples listed and discussed above were specifically chosen to show how different sentences can appear " incompatible» when isolated and deprived of tangible context. Seen against the background of relevant context, however, the same sentences acquire meaning, or more meaning, for context creates the extra-linguistic layer without which words would remain an indecipherable code.

Incompatibility is then seen here as not necessarily amounting to inexactitude or absolute indeterminacy in translation as imagined by Quine.

Those are some of the points which Quine's critics have failed to notice, or stress clearly, for reasons already given above. For instance, without calling attention to the absence of a definite context in Quine's hypotheses, Robert Kirk has tried, painstakingly, to refute the thesis of indeterminacy. And so he agrees with Quine that both target language sentences are equivalent to the same source text, but goes on to try to prove that, contrary to Quine's idea, bilinguals can translate correctly (Kirk, 1969, p. 341):

the mistake was to assume that two such bilinguals could produce seriously discrepant translations of the same sentence, without its being possible to show that one or other of them was incorrect. Contrary to Quine's opinion, a true bilingual is « in a position to make uniquely right correlations of sentences between languages ". So if a linguist constructs analytical hypotheses, there is something objective for him to be right or wrong about.

Kirk also appears not to know, or chooses to ignore, the fact that not all «true" bilinguals have internalized their code-switching ability enough to cover that of actual translation. At any rate, he does not put himself in a position where he can confirm or negate Quine's thesis.

Moreover, A. Hyslop has shown what is wrong in one other principle on which Kirk bases his criticism of Quine's view. That is, the assumption that when a bilingual 
repeats a sentence in SL and then quotes himself in another language TL using the indirect speech, but keeping the exact SL words, his speech must be intelligible. The example given by Kirk was "I said that $\mathrm{SA}$; my actual words were « $S$ ". Hyslop rightly shows that the content of such a statement might in fact be unintelligible hence "I said I was mad; my actual words were " Je suis blanc", which would then be rendered by "J'ai dit que j’étais fou; mes paroles véritables étaient «Je suis blanc» (Hyslop, 1972, p. 271-272). The point made here is that if the source language statement itself not intelligible to start with, the target language text cannot be blamed for being unintelligible. Kirk apparently had not thought of this point, and so it was possible to prove him wrong on his stand against Quine from another angle.

One other response to Kirk stresses the point about comparing incomparables, i.e. putting original and translation on the same pedestal. We said earlier that a source language text is relatively static, actual, whereas translation is virtual, depending on individual and critical interpretation. Roy Harris (1972) makes a relevant case when he points out in reply to Kirk: "There must be parity in test of «intelligilibity » as between a sentence and its translation in respect of « intelligibility » when the whole of the one is assigned an interpretation, while part of the other is assigned no interpretation."

We shall now try to state in broad outlines how a comprehensive and systematic approach to translation criticism, in the light of the latest findings in translation studies, can refute the thesis of indeterminacy.

The model here must take for granted that the critic himself is not only at home in the pair of languages in contact, but also familiar with the two « worlds " from which the texts involved emanate. It goes without saying too that all that constitutes what Brian Harris would like to call translatology holds no secret for the translation critic. The sort of text we have in mind here is the literary one, say a novel, for literary translation offers the best chances of bringing together within the same text the different types of translation problems, linguistic, literary, and cultural, and even problems relating to technical terminology. The type of criticism outlined here, other than making it possible to actually determine the indeterminate in questions pertaining to translation, has the added advantage of possibly leading, each time, to translation theory. This is so inasmuch as the symbiotic relationship between translation as object of study ("theorem ") and criticism as systematized observation ("theory") of translation can be brought to the fore in this manner. What we are dealing with here are two different processes. The one constitutes the passage between a source text (SL) and a target text (TL), the other leads from the finished product (TL) to the critical text (TLC). We are mainly concerned with only the second process (TLC), which highlights Quine's query against translation.

With regard to the translation of a literary work of art, it should be noted that the original text (SL) is itself preceded by the "moment " of composition (Fig. 1):

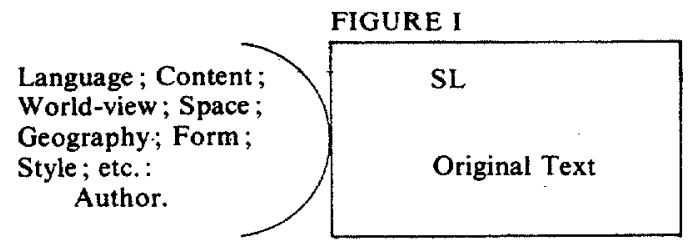


The incomplete circle above represents the universe of the original author, a world to which access can only now be partial. The square stands for $S L$ text, relatively fixed, to which the translator will address himself. The second diagram (Fig. 2) below, roughly contains what the translator brings into his work:

\section{FIGURE II}

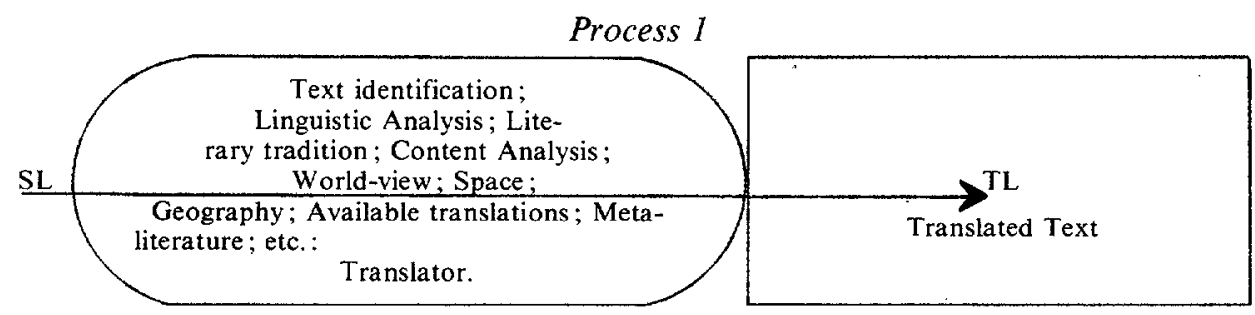

The square represents the translated work, the end-point of the first process. It will be noticed that the translator's circle also takes into account any former translations of the work that may have been done, as well as what Holmes (1970) has termed «metaliterature», such as critical material and works inspired by the original, or its translations, e.g. «imitations » and other interpretations of the work, like the pastiche, cento (music and literature), meta-poem (poetry) and adaptation (drama). Note should also be taken of the different levels of analysis, which are essential elements in the process of aiming at equivalence.

As for the critic's circle (Fig. 3), it is made up of elements which will determine the critic's evaluation of TL:

\section{FIGURE III}

Process 2

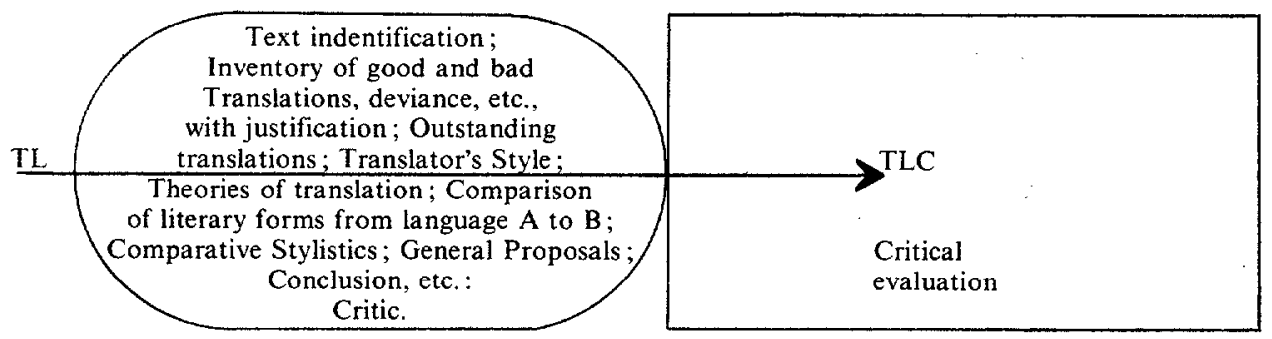

There are five main steps. After initial detailed study of both original and translation, the first step leads to text identification. Then negative and positive aspects of the TL are noted. Since the greater part of the text would normally be well translated, this second step can afford to concentrate on the negative points, explain reasons for mistakes and propose correct renderings. The third step examines outstanding translation, if any. Cases where the translator succeeds in creating correct equivalence not yet given in dictionaries should be noted. The fourth point concerns the translator's style, techniques used in carrying meaning and form across to the other language. Word-count will help the critic to note objectively the translator's preference of certain techniques to others (cf. "modulation", "transposition"). The fifth and final important point relates the translator's work to other translations and 
translation studies in general: equivalence of literary forms across languages, comparative stylistics, etc. The critic may, for instance, show how the translation in question confirms or disproves certain hypotheses.

The real conclusion of this type of work will be a general judgment on the work, stating whether the translation is adequate in part or as a whole, whether there is need for partial or total retranslation. Other translations of the work, if available, will be compared, and judgment passed. The extent to which previous translations were used should be touched upon. If there is evidence of plagiarism, it should be pointed out, in view of copyright implications. Besides, practices which could tarnish the image and reputation of the profession must thus be discouraged.

From all the foregoing, it can be seen that through a comprehensive and systematic approach to translation criticism, the margin of indeterminability can be reduced to the barest minimum and Quine's thesis disproved from a fresh angle.

EKUNDAYO SIMPSON

\section{REFERENCES}

Only works mentioned in this essay. Works containing important bibliographies on translation are indicated with an asterisk (*).

1. ARROWSMITH, William and Roger SHATTUCK, eds., The Craft and Context of Transiation, Austin, Texas, University of Texas Press, 1961.

2. BRISLIN, Richard, ed.," Translation: Application and Research, New York, Gardner Press, 1976.

3. BROWER, Reuben, ed., * On Translation, Cambridge (Mass.), Harvard University Press, 1959.

4: CATFORD, J.C., A Linguistic Theory of Translation: An Essay on Applied Linguistics, London, Oxford University Press, 1965.

5. HARRIS, Brian, "Toward a Science of Translation", Meta, 22 (March, 1977), p, 91-92.

6. HAR RIS, Roy, "Translation into Martian", Mind, LXXXI (1972, p. 276.

HYSLOP, A., "Kirk on Quine on Bilingalism», Mind, LXXXI (1972), p. 271-272.

7. HOLMES, James S., The Nature of Translation, The Hague, Mouton, 1970.

8. KIRK, Robert, "Translation and Indeterminacy", Mind, LXXVIII (July, 1969), p. 321-341.

9. MACKEY, William F., "Interference, Integration and the Synchronic Fallacy", James E. Alatis, Bilingualism and Linguistics 1970, Washington, Georgetown University Press, 1970, p. 195-227.

10. MOUNIN, Georges, les Problèmes théoriques de la traduction, Paris, Gallimard, 1963.

11. Linguistique et traduction, Brussels, Dessart et Mardaga, 1976.

12. NIDA, Eugène, * Toward a Science of Translating, Leiden, E. J. Brill, 1964.

13. "A Framework for the Analysis and Evaluation of Theories of Translation", Richard W. Brislin, ed., Translation: Applications and Research, p. 44-91.

14. NIDA, Eugène and C. TABER, * The Theory and Practice of Translation, Leiden, E. J. Brill, 1969.

15. POPOVIC, Anton, "The Concept "Shift of Expression", James, S. Holmes, The Nature of Translation, p. 78-87.

16. QUINE, Willard Van Orman, « Meaning and Translation", Reuben A. Brower, ed., On Translation, p. $143-172$.

17. Word and Object, Cambridge (Mass.), M.I.T. Press, 1960.

18. SIMPSON, Ekundayo, "Methodology in Translation Criticism», Meta, 20 (Dec. 1975), p. $251-262$.

19. STEINER, George, Extraterritorial: Papers on Literature and the Language Revolution, New York, Athenium, 1971.

20. Athenium, *After Babel: Aspects of Language and Translation, London, Oxford University Press, 1975.

21. VINAY, Jean-Paul, * Regards sur l'évolution des théories de la traduction depuis vingt ans ", Meta, 20 (March, 1975) (Special Issue: Vingt ans de traduction: Bilan et prospectives), p. 7-27.

22. VINAY, Jean-Paul and Jean DARBELNET, *Stylistique comparée du français et de l'anglais: méthode de traduction, Montréal, Beauchemin, 1958 (revised version 1970). 